\title{
A Retrospective Examination of 2012 Fuel Subsidy Removal Crisis in Nigeria: Content Analysis of Selected National Daily Newspapers
}

\author{
Adeyemi Aderogba Ph.D \\ Osun State University \\ Department of Languages and Linguistics College of Humanities and Culture Ikire Campus, Nigeria
}

\begin{abstract}
Nigerian government has over the years made several unsuccessful attempts at removing fuel subsidy. The attempt made in 2012 led to a nation-wide carnival-like protests in all the major cities of the country The protests which involved workers of both formal and informal sectors of the economy as well as the unemployed youths disrupted economic activities in the country for almost two weeks. The research reported in this paper is based on a content analysis of four Nigerian national newspapers and their coverage of the protests that greeted the fuel subsidy removal. The Social Responsibility Theory of the Press was considered relevant to the study. It was discovered that most of the stories published in the newspapers i.e. 63.4 percent of the stories were against the removal of fuel subsidy. The study also showed that one of the major problems plaguing the Nigerian oil industry is that of corruption, which was under reported by the media with a meagre 1.89 percent of the total stories. The paper thus notes that despite advantages of deregulation in the petroleum industry, the Nigerian government needs to consider people's interest in its policy formulation and implementation and also tackle corruption in the oil industry.
\end{abstract}

Keywords - Anti-subsidy removal, corruption, fuel subsidy removal, oil industry, pro-subsidy removal.

\section{INTRODUCTION}

Nigerian society is plagued by so many challenges but there has never been any issue in the country in contemporary time that is as contentious as fuel subsidy removal. It is an issue that appears to be a recurring dilemma since 1973. Nearly all the successive governments grappled with this problem. The argument that ensues between two opposing groups in Nigeria is whether or not the Federal Government of Nigeria really subsidizes fuel. Opponents of fuel subsidy removal believe that there is no subsidy on petrol at all (Nwachukwu \& Chike 1, Agbon 2 and Ifoh 3). But supporters of subsidy removal think otherwise, to them, the only way forward is for the government to stop subsidizing petrol (Soile \& Mu 4, Nwachukwu, Mba, Jiburum \& Okosun 5, Nwachukwu 6 and Nanaghan7) Subsidy is a well known government policy around the world as quite a number of countries across the globe have adopted different kinds of subsidy policies in order to provide succors for its businesses and citizens. Subsidy, according to Merriam-Webster Dictionary, is the money that is paid usually by government to keep the price of product or service low to help improve businesses. https://www.merriam-webster.com/dictionary/subsidy

The Oxford Dictionary defines it as "a sum of money granted by the state or a public body to help an industry or business keep the price of a commodity or service low". It could also be described as "a sum of money granted to support an undertaking held to be in the public interest". The Organization for Economic Cooperation and Development (OECD), for its part, describes subsidies as "a measure that keeps prices for consumers below market levels, or keeps prices for producers above market levels or that reduces costs for both producers and consumers by giving direct or indirect support" (8).Subsidies could come in the form of grants and other direct payments. Based on this fact, tax concessions, in-kind subsidies, cross subsidies, credit subsidies and government guarantees, hybrid subsidies, subsidies through government procurement, derivates subsidies and market price support are all identified forms of subsidies (9). Most economists believe that there is actually no economic sense in subsidies of any kind because it is like robbing Peter to pay Paul. It has been argued severally that money put into subsidy by the government can find better usage in the provision of better health care delivery service, in education or in building better infrastructural facilities (10). Fuel subsidy is a kind of government grant or direct payments. Fuel subsidy in Nigeria, just like in other countries of the world, is unsustainable. This is because fuel bills grow bigger each year. Soile and $\mathrm{Mu}$ (4) citing the International Monetary Fund affirm that "the global value of subsidies for fossil fuel consumption grew from $\$ 312$ billion in 2009 to $\$ 548$ billion in 2013". 
Nigeria is listed by International Energy Agency (IEA) in 2013 to be among the top 20 countries in the world that heavily subsidize fossil fuel consumption. This sort of scenario adversely affects other sectors of the economy.

Scholars believe that some of the problems in the downstream sector of Nigerian petroleum industry are due to abysmal mismanagement of the sector by successive governments coupled with low pump price of petrol in Nigeria which, according to them, encourages smuggling of the product into neighbouring countries where prices are higher Ascher (11), Okogu (12) and Akov (13).

Huge benefits that are derivable from fuel subsidy removal notwithstanding, the policy is a knotty one and Nigerian government seems to lack the political will to implement it out rightly for socio political reasons rather than economic. This same challenge is what Widodo et al term "political consideration" Widodo et al (14).

Any attempt at removing fuel subsidy in Nigeria usually translate to correspondent increase in prices of other goods and services thereby leading to rise in the cost of living of the people, majority of whom are impoverished Onyeizugbe \& Onwuka (15). This is what Akanle \& Adetayo (16) call "negative ripple effects on consumer goods", a situation that aggravates the poverty level in the society. Living conditions in Nigeria is terribly low even with fuel subsidy in place.

Odusola (17) affirms that "Sub-Saharan African countries are noted for prevalence of absolute poverty in all its characteristic features. Poverty in these countries is massive, pervasive and chronic, engulfing a large proportion of the society". Nwaoga \& Casimir (18) posit that "Removing the oil subsidy is like removing two square meals from the tables of over one hundred and forty million Nigerians. Immediately the subsidy was removed and the price of fuel increased, there were multiple increases in prices of goods and services in Nigeria, e.g., there were astronomical increase in tuition fees, transportation, house rents, food items, and other basic commodities. This gave room for multiple increases in the prices of goods and services in Nigeria".

Controversy of fuel subsidy removal in Nigeria is never ending as every successive government made attempts at removing subsidy against the wishes of overwhelming majority of Nigerians. The government attempted to remove fuel subsidy 24 times from 1973 to 2012. President Buhari already made an attempt to do the same thing in 2016. The table below shows details of such attempts.

1.1. Table 1. Showing the number of time petrol prices were adjusted in Nigeria since 1973

\begin{tabular}{|c|c|c|c|c|c|c|c|}
\hline \multirow{2}{*}{$\begin{array}{l}\mathbf{S} / \\
\mathbf{N}\end{array}$} & \multirow[t]{2}{*}{ Date } & \multirow{2}{*}{$\begin{array}{l}\text { Administrati } \\
\text { on }\end{array}$} & \multicolumn{3}{|c|}{ Price } & \multirow{2}{*}{$\begin{array}{l}\text { Percentag } \\
\text { e Change }\end{array}$} & \multirow[t]{2}{*}{ Remark } \\
\hline & & & $\begin{array}{l}\text { Old } \\
\text { Price }\end{array}$ & $\begin{array}{l}\text { New } \\
\text { Price }\end{array}$ & $\begin{array}{l}\text { Amount } \\
\text { Settled for }\end{array}$ & & \\
\hline 1 & 1973 & Gowon & $6 \mathrm{~K}$ & $8.5 \mathrm{~K}$ & $8.45 \mathrm{~K}$ & 40.8 & \\
\hline 2 & 1976 & Murtala & $8.45 \mathrm{~K}$ & $9 \mathrm{~K}$ & $9 \mathrm{~K}$ & 6.5 & \\
\hline 3 & 1978 & Obasanjo & $9 \mathrm{~K}$ & $15.3 \mathrm{~K}$ & $15.3 \mathrm{~K}$ & 15.9 & \\
\hline 4 & 1982 & Shagari & $15.3 \mathrm{~K}$ & $20 \mathrm{~K}$ & $20 \mathrm{~K}$ & 30.7 & \\
\hline 5 & 1986 & Babangida & $20 \mathrm{~K}$ & $39.5 \mathrm{~K}$ & $39.5 \mathrm{~K}$ & 97.5 & \\
\hline 6 & 1988 & Babangida & $39.5 \mathrm{~K}$ & $42 \mathrm{~K}$ & $42 \mathrm{~K}$ & 6.3 & \\
\hline 7 & 1989 & Babangida & $42 \mathrm{~K}$ & $60 \mathrm{k}$ & $60 \mathrm{~K}$ & 42.9 & $\begin{array}{l}\text { First nation-wide } \\
\text { protest }\end{array}$ \\
\hline 8 & 1991 & Babangida & $60 \mathrm{k}$ & $70 \mathrm{~K}$ & $70 \mathrm{k}$ & 16.7 & \\
\hline 9 & 1993 & $\begin{array}{l}\text { Ernest } \\
\text { Shonekan }\end{array}$ & $70 \mathrm{~K}$ & $\mathrm{N5.00 \textrm {K }}$ & $\mathrm{N5.00 \textrm {K }}$ & 614 & \\
\hline 10 & 1993 & Abacha & $\$ 5.00 \mathrm{~K}$ & $\mathrm{~N} 3.25 \mathrm{~K}$ & $\mathrm{~N} 3.25 \mathrm{~K}$ & -35 & $\begin{array}{l}\text { Reduction in } \\
\text { price }\end{array}$ \\
\hline 11 & 1994 & Abacha & \#3.25K & $¥ 15.00 \mathrm{~K}$ & $\mathrm{~N} 15.00 \mathrm{~K}$ & 361 & \\
\hline 12 & 1994 & Abacha & $\begin{array}{l}\text { N15.00 } \\
\mathrm{K}\end{array}$ & $\mathrm{N} 15.00 \mathrm{~K}$ & $\mathrm{~N} 11.00 \mathrm{~K}$ & -26.6 & $\begin{array}{l}\text { Reduction in } \\
\text { price }\end{array}$ \\
\hline 13 & 1998 & Abubakar & $\begin{array}{l}\text { N11.00 } \\
\text { K }\end{array}$ & $¥ 25.00 \mathrm{~K}$ & $\mathrm{~N} 25.00 \mathrm{~K}$ & 127.3 & \\
\hline 14 & 1999 & Abubakar & $\begin{array}{l}N 25.00 \\
K\end{array}$ & $\mathrm{~N} 25.00 \mathrm{~K}$ & $\approx 20.00 \mathrm{~K}$ & 20 & $\begin{array}{l}\text { Reduction in } \\
\text { price }\end{array}$ \\
\hline 15 & 2000 & Obasanjo & $\begin{array}{l}¥ 20.00 \\
\mathrm{~K}\end{array}$ & $\$ 30.00 \mathrm{~K}$ & $\$ 30.00 \mathrm{~K}$ & 50 & \\
\hline 16 & 2000 & Obasanjo & $\$ 30.00 \mathrm{k}$ & $¥ 22.00 \mathrm{~K}$ & $\mathrm{~N} 22.00 \mathrm{~K}$ & 26.7 & $\begin{array}{l}\text { Reduction } \\
\text { price }\end{array}$ \\
\hline
\end{tabular}


A Retrospective Examination of 2012 Fuel Subsidy Removal Crisis in Nigeria:

\begin{tabular}{|c|c|c|c|c|c|c|c|}
\hline 17 & 2002 & Obasanjo & $\begin{array}{l}\text { N22.00 } \\
\mathrm{K}\end{array}$ & N26.00K & $\mathrm{N} 26.00 \mathrm{~K}$ & 15.3 & \\
\hline 18 & 2003 & Obasanjo & $\begin{array}{l}\text { N26.00 } \\
\mathrm{K}\end{array}$ & N42.00K & $\mathrm{N} 42.00 \mathrm{~K}$ & 61.5 & \\
\hline 19 & 2004 & Obasanjo & $\begin{array}{l}N 42.00 \\
\mathrm{~K}\end{array}$ & $\approx 50.00 \mathrm{~K}$ & $\mathrm{N50.00 \textrm {K }}$ & 19 & \\
\hline 20 & 2004 & Obasanjo & $\begin{array}{l}\text { N50.00 } \\
\text { K }\end{array}$ & $¥ 65.00 \mathrm{~K}$ & $\mathrm{N65.00 \textrm {K }}$ & 30 & \\
\hline 21 & 2007 & Obasanjo & $\begin{array}{l}N 65.00 \\
\mathrm{~K}\end{array}$ & $\mathrm{N5.00 \textrm {K }}$ & 丹75.00K & 15.4 & \\
\hline 22 & 2007 & Yar' Adua & $\begin{array}{l}\text { N75.00 } \\
\text { K }\end{array}$ & $¥ 65.00 \mathrm{~K}$ & N65.00K & -13.3 & $\begin{array}{l}\text { Reduction in } \\
\text { price }\end{array}$ \\
\hline 23 & 2012 & Jonathan & $\begin{array}{l}\text { N65.00 } \\
\text { K }\end{array}$ & $141.00 \mathrm{~K}$ & $97.00 \mathrm{~K}$ & 49.2 & \\
\hline 24 & 2015 & Jonathan & $\begin{array}{l}\text { N97.00 } \\
\text { K }\end{array}$ & $\cong 86.50 \mathrm{~K}$ & 886.50K & 10.8 & $\begin{array}{l}\text { Reduction in } \\
\text { price }\end{array}$ \\
\hline 25 & 2016 & Buhari & $\begin{array}{l}\mathrm{N} 86.50 \\
\mathrm{~K}\end{array}$ & $\cong 85.50 \mathrm{~K}$ & $\mathrm{~N} 85.50 \mathrm{~K}$ & 1.2 & $\begin{array}{l}\text { Reduction in } \\
\text { price }\end{array}$ \\
\hline 26 & 2016 & Buhari & $\begin{array}{l}\mathrm{N} 86.50 \\
\mathrm{~K}\end{array}$ & $145.00 \mathrm{~K}$ & N145.00K & 67.6 & \\
\hline
\end{tabular}

Source: Adeyemi and Olanipekun (10).

Fuel subsidy removal protests that took place in Nigeria in 2012 was one of the most celebrated protests ever in the history of the country. The protests brought together all categories of workers, artisans, people in the entertainment industry, famers, human right activists, academia, opposition politicians and indeed virtually all the cross section of Nigerian society. Majority of Nigerians could not understand why they should be made to pay so much for resources nature gave them in abundance as the country is reputed to be the $6^{\text {th }}$ largest exporter of petroleum in the world. Nigerians usually resist any attempt by government to increase fuel price under any disguise such as deregulation or commercialization of petroleum sector etc.

\section{I.2 WHY IS SUBSIDY REMOVAL ESSENTIAL?}

Ordinarily, subsidy removal couldn't have been a necessity except that government revenue is not growing in the same proportion with the expenditure. This situation is most critical in the developing nations where government is under constant budgetary pressure. Government revenue is meagre, population is huge and ever-growing, overwhelming majority of the populace lives in abject poverty and there is also massive infrastructural deficit in most cases and host of other problems.

Azis Iwan (19) writes, "in order to reduce the mounting pressure on government budget due to rising expenditures related to all sorts of subsidies, including those for the banking sector and domestic fuel consumption, the Indonesian Government has opted to cut only the fuel subsidies. Following the surge of the world price of oil, the size of the cut was huge, causing the average domestic fuel prices to increase by more than 120 per cent".

The situation in Indonesia regarding fuel subsidy is similar to that of Nigerian, as Nigeria has so many things in common with Indonesia. The two countries have huge population, they have development challenges, they are both developing with large population of poor people and (until recently) they were both members of OPEC etc.The belief is that money saved from fuel subsidy removal could be ploughed into other needy sectors of the society. This is true in most developing nations of the world and Nigeria is not an exception. There is dearth of infrastructural development in Nigeria and several billions of US dollars are required to fix the deficit.

\section{OBJECTIVES OF THE STUDY}

The researcher put forward the following objectives:

1. To examine the most important issues covered by the press during the period of fuel subsidy removal crisis.

2. To find out the prominence given to fuel subsidy removal by the Nigerian press.

3. To find out the most important story theme that attracted the attention of the Nigerian press.

The following research questions were therefore examined:

1. What were the most important issues covered by Nigerian press during the period of fuel subsidy removal crisis?

2. What was the level of prominence accorded fuel subsidy removal by the Nigerian press?

3. What was the most important story theme covered by the Nigerian press? 


\subsection{OPERATIONAL DEFINITIONS}

Prominence: The placement of stories/illustrations on different pages of the newspapers tells much about the prominence of such items. Front-page as well as back-page materials of the selected newspapers were considered to be more prominent than those that were buried inside the newspapers.

Pro-subsidy removal: Newspaper stories in support of subsidy removal.

Anti-subsidy removal: Newspaper stories that were not in favour of subsidy removal.

Corruption in the oil industry: Newspaper publications on corruption in the oil industry.

Inefficiency of the refineries: Newspaper stories on inefficiency in Nigerian refineries.

Call for strike: Newspaper materials in support of strike action.

Slant: This is all about the tone of stories towards the government. The slant could either be positive, negative and neutral.

Violence/Causality: Newspaper stories on violent incidents/fatality.

\section{III.}

\section{THEORETICAL FRAMEWORK}

Social Responsibility Theory

Social Responsibility Theory is considered relevant to this study because of the underlying principles of the theory as has been pointed out by McQuail (20). According to the scholar, the media should accept and fulfill certain obligations to society. These obligations can only be met by setting high standards of informativeness, truth, accuracy, objectivity and balance. In accepting and carrying out these obligations, the media should be self-regulating within the framework of the law and established institutions. Journalists and media professionals should be accountable to the society as well as to their employers and the market. An accountable media practitioner would be truthful, accurate and objective as well as balanced. Adeyemi (21).

\section{METHOD}

Four national newspapers were randomly selected through blind balloting to be content analyzed. Names of all well-known newspapers that enjoy national spread were written on small pieces of paper that were then squeezed and thrown into a basket. After thorough shuffling, four strangers were invited to pick one each. The following newspapers were picked: The Guardian, The Punch, This Day and Compass newspapers.

\subsection{Study Period}

The study covered $1^{\text {st }}$ to $15^{\text {th }}$ January 2012 , the period of the crisis. The crisis began when on $1^{\text {st }}$ January, 2012, President Jonathan announced the removal of fuel subsidy and ended immediately the strike action was called off on 15 January, 2012.

\subsection{Study Universe}

A total of 60 copies of the four selected newspapers were thoroughly examined and 1,243 stories were found to be relevant to the study. Out of this number, 437 stories, or 35.15 percent of all the stories, appeared in the Punch, while the Guardian accounted for 322 stories, or 25.91 percent. This Day's share of the stories was 290, or 23.33 percent, while the Compass accounted for 194 or 15.61 percent of all the stories published by the four newspapers.

4.3 Unit of Analysis

Units of analysis of this study include story headline, entire story, picture, cartoon and any other illustration.

\section{RESULT}

The data that forms the basis of the findings are presented in tables below:

Table 1 Story type

\begin{tabular}{|c|c|c|c|c|c|c|c|c|c|c|c|c|c|c|c|c|}
\hline \multirow{2}{*}{$\begin{array}{l}\text { Newsp } \\
\text { aper } \\
\text { The } \\
\text { Punch }\end{array}$} & \multicolumn{2}{|c|}{$\begin{array}{l}\text { News } \\
\text { story }\end{array}$} & \multicolumn{2}{|c|}{ Feature } & \multicolumn{2}{|c|}{$\begin{array}{l}\text { Editoria } \\
1\end{array}$} & \multicolumn{2}{|c|}{$\begin{array}{l}\text { News } \\
\text { analysi } \\
\text { s }\end{array}$} & \multicolumn{2}{|c|}{$\begin{array}{l}\text { Intervie } \\
\mathrm{w}\end{array}$} & \multicolumn{2}{|c|}{$\begin{array}{l}\text { Pictorial } \\
\text { illustratio } \\
n\end{array}$} & \multicolumn{2}{|c|}{$\begin{array}{l}\text { Adverto } \\
\text { rial }\end{array}$} & \multicolumn{2}{|c|}{ Total } \\
\hline & $\begin{array}{l}\text { Fr } \\
\text { eq. } \\
27 \\
0\end{array}$ & $\begin{array}{l}\% \\
21 \\
.7 \\
2\end{array}$ & $\begin{array}{l}\text { Fr } \\
\text { eq. } \\
52\end{array}$ & $\begin{array}{l}\% \\
4 . \\
18\end{array}$ & $\begin{array}{l}\text { Fre } \\
\text { q. } \\
4\end{array}$ & $\begin{array}{l}0 . \\
3 \\
2\end{array}$ & $\begin{array}{l}\text { Fr } \\
\text { eq. } \\
3\end{array}$ & $\begin{array}{l}0 . \\
2 \\
4\end{array}$ & $\begin{array}{l}\text { Fre } \\
\text { q. } \\
0\end{array}$ & 0 & $\begin{array}{l}\text { Freq } \\
108\end{array}$ & $\begin{array}{l}8 . \\
69\end{array}$ & $\begin{array}{l}\text { Fre } \\
\text { q. } \\
0\end{array}$ & 0 & $\begin{array}{l}\text { Fr } \\
\text { eq. } \\
43 \\
7\end{array}$ & $\begin{array}{l}35 . \\
15\end{array}$ \\
\hline $\begin{array}{l}\text { The } \\
\text { Guardi } \\
\text { an }\end{array}$ & $\begin{array}{l}11 \\
5\end{array}$ & $\begin{array}{l}9 . \\
25\end{array}$ & $\begin{array}{l}10 \\
3\end{array}$ & $\begin{array}{l}8 . \\
29\end{array}$ & 3 & $\begin{array}{l}0 . \\
2 \\
4\end{array}$ & 6 & $\begin{array}{l}0 . \\
4 \\
8\end{array}$ & 9 & $\begin{array}{l}0 . \\
7 \\
2\end{array}$ & 75 & 03 & 11 & $\begin{array}{l}0 . \\
8 \\
8\end{array}$ & $\begin{array}{l}32 \\
2\end{array}$ & $\begin{array}{l}25 . \\
91\end{array}$ \\
\hline
\end{tabular}




\begin{tabular}{|l|l|l|l|l|l|l|l|l|l|l|l|l|l|l|l|l|}
\hline This & 17 & 13 & 55 & 4. & 3 & 0. & 8 & 0. & 8 & 0. & 33 & 2. & 10 & 0. & 29 & 23. \\
Day & 3 & .9 & & 42 & & 2 & & 6 & & 6 & & 65 & & 8 & 0 & 33 \\
& & 2 & & & & 4 & & 4 & & 4 & & & & & & \\
Compa & 12 & 10 & 18 & 1. & 1 & 0. & 0 & 0 & 6 & 0. & 36 & 2. & 6 & 0. & 19 & 15. \\
ss & 7 & .2 & & 45 & & 0 & & & & 4 & & 89 & & 4 & 4 & 61 \\
& & 3 & & & & 8 & & & & 8 & & & & 8 & & \\
\hline Total & 68 & 55 & 22 & 18 & 11 & 0. & 17 & 1. & 23 & 1. & 252 & 20 & 27 & 2. & $\mathrm{~N}=1243$ \\
& 5 & .1 & 8 & .3 & & 8 & & 3 & & 8 & & .2 & & 6 & or $100 \%$ \\
& & 5 & & 4 & & 8 & & 4 & & 5 & & 6 & & & \\
\hline
\end{tabular}

Stories published on fuel subsidy crisis belonged to different story genres. According to table 1, slightly more than half of the materials, that is 685 , or 55.15 percent, were news stories. This is followed by feature stories with 228, or 18.34 percent. Editorials had the lowest share with 11 or 0.88 percent.

Table 2 Prominence

\begin{tabular}{|c|c|c|c|c|c|c|c|c|}
\hline \multirow{2}{*}{ Newspaper } & \multicolumn{2}{|c|}{ Front Page } & \multicolumn{2}{|c|}{ Back Page } & \multicolumn{2}{|c|}{ Inside Page } & \multicolumn{2}{|l|}{ Total } \\
\hline & Freq & $\%$ & Freq & $\%$ & Freq & $\%$ & Freq & $\%$ \\
\hline The Punch & 29 & 2.33 & 4 & 0.32 & 404 & 32.5 & 437 & 35.15 \\
\hline The Guardian & 25 & 2.01 & 6 & 0.48 & 291 & 23.41 & 322 & 25.91 \\
\hline This Day & 26 & 2.09 & 2 & 0.16 & 262 & 21.07 & 290 & 23.33 \\
\hline Compass & 15 & 1.21 & 3 & 0.24 & 176 & 10.94 & 194 & 15.61 \\
\hline Total & 95 & 7.64 & 15 & 1.2 & 1133 & 87.92 & $\begin{array}{l}\mathrm{N}=12 \\
100 \%\end{array}$ & or \\
\hline
\end{tabular}

During the 15 days covered by the study, the crisis dominated the four selected newspapers as fuel subsidy issue was given better coverage more than any other matter during the period under consideration. 95 or 7.64 percent, of the total number of stories made it to the front page, while as much as 1133 , or 87.92 percent, were buried in the inside pages. The back pages are usually mostly dedicated to sports, only 15 , or 1.2 percent, of the articles appeared on the back page.

Table 3 Slant

\begin{tabular}{|c|c|c|c|c|c|c|c|c|}
\hline \multirow[b]{2}{*}{ NEWSPAPER } & \multicolumn{2}{|c|}{ Positive } & \multicolumn{2}{|c|}{ Negative } & \multicolumn{2}{|c|}{ Neutral } & \multicolumn{2}{|l|}{ Total } \\
\hline & Freq & $\%$ & Freq & $\%$ & Freq & $\%$ & Freq & $\%$ \\
\hline The Punch & 42 & 3.38 & 371 & 29.85 & 24 & 1.93 & 437 & 35.15 \\
\hline The Guardian & 54 & 4.34 & 238 & 19.15 & 30 & 2.41 & 322 & 25.91 \\
\hline This Day & 71 & 5.71 & 188 & 15.12 & 30 & 2.41 & 290 & 23.33 \\
\hline Compass & 35 & 2.82 & 149 & 12 & 10 & 0.8 & 194 & 15.61 \\
\hline Total & 202 & 16.25 & 946 & 76.12 & 94 & 7.56 & $\mathrm{~N}=124$ & $100 \%$ \\
\hline
\end{tabular}

Table 3 shows that 76.12 percent of stories published in the four papers were negative toward the government, 16.25 percent were positive, while just 7.56 percent were neutral.

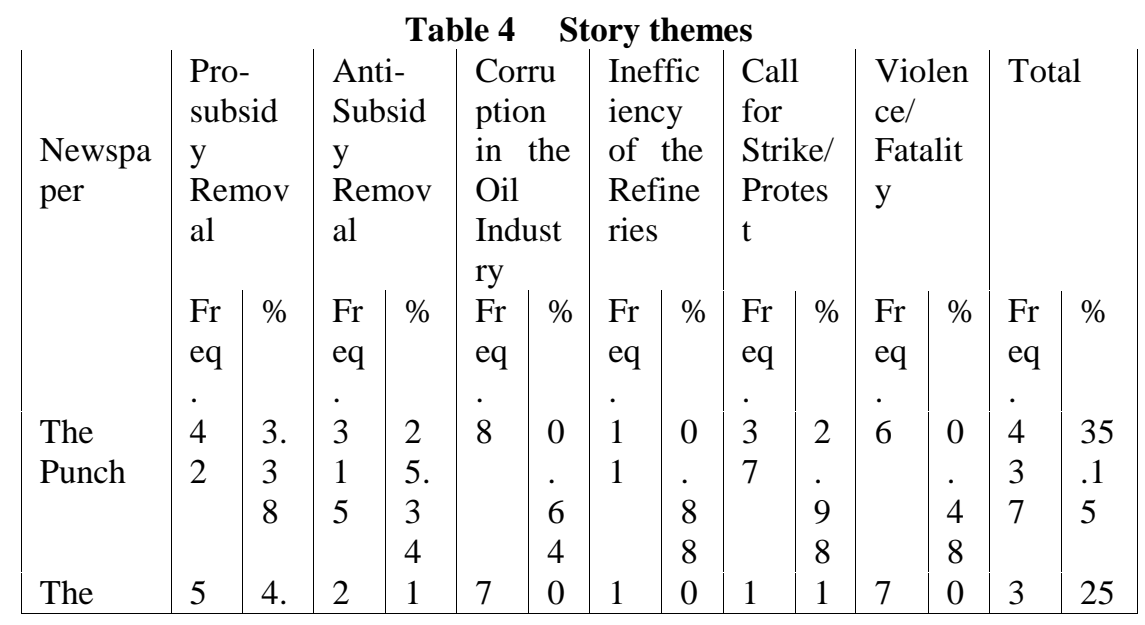




\begin{tabular}{|l|l|l|l|l|l|l|l|l|l|l|l|l|l|l|}
\hline Guardia & 3 & 2 & 1 & 7. & &. & &. & 8 &. & &. & 2 & .9 \\
n & & 6 & 5 & 3 & & 5 & & 0 & & 4 & & 5 & 2 & 1 \\
This & 6 & 5. & 1 & 1 & 1 & 0 & 2 & 0 & 2 & 0 & 1 & 0 & 2 & 23 \\
Day & 8 & 4 & 5 & 2. & &. & &. & 0 &. & 0 &. & 9 &. .3 \\
& & 7 & 4 & 3 & & 0 & & 1 & & 1 & & 8 & 0 & 3 \\
& & & & 9 & & 8 & & 6 & & 6 & & & & \\
\hline Compa & 3 & 2. & 1 & 8. & 2 & 0 & 1 & 0 & 1 & 0 & 1 & 1 & 1 & 15 \\
ss & 4 & 7 & 0 & 3 & &. & 1 &. & 2 &. & 4 &. & 9 & .6 \\
& & 4 & 4 & 7 & & 6 & & 8 & & 9 & & 1 & 4 & 1 \\
& & & & & & 1 & & 8 & & 7 & & 3 & & \\
\hline Total & 1 & 1 & 7 & 6 & 1 & 1 & 2 & 2 & 8 & 5 & 3 & 2 & $\mathrm{~N}=$ \\
& 9 & 5. & 8 & 3. & 8 &. & 5 &. & 7 &. & 7 &. & 1243 or \\
& 7 & 8 & 8 & 4 & & 8 & & 0 & & 5 & & 9 & $100 \%$ \\
& & 5 & & & & 9 & & 1 & & 6 & & 7 & \\
\hline
\end{tabular}

Table 4 reveals that 63.4 percent of all the stories published in newspapers selected for this study were against subsidy removal, 15.85 percent were for subsidy removal, 5.56 percent of all the stories were in support of the strike/protest, 2.97 were on violence/fatality, 2.01 percent were on inefficiency of the country's refineries and 1.89 percent of all the materials were on corruption in the oil industry.

Table 5 Source

\begin{tabular}{|c|c|c|c|c|c|c|c|c|c|c|c|c|}
\hline \multirow{2}{*}{$\begin{array}{l}\text { Newspap } \\
\text { er }\end{array}$} & \multicolumn{2}{|c|}{$\begin{array}{l}\text { Governme } \\
\mathrm{nt}\end{array}$} & \multicolumn{2}{|c|}{$\begin{array}{l}\text { Non- } \\
\text { Governme } \\
\text { nt }\end{array}$} & \multicolumn{2}{|c|}{ Foreign } & \multicolumn{2}{|c|}{ Individual } & \multicolumn{2}{|c|}{$\begin{array}{l}\text { News } \\
\text { Agency }\end{array}$} & \multicolumn{2}{|l|}{ Total } \\
\hline & $\begin{array}{l}\text { Fre } \\
\text { q. }\end{array}$ & $\%$ & $\begin{array}{l}\text { Fre } \\
\text { q. }\end{array}$ & $\%$ & $\begin{array}{l}\text { Fre } \\
\text { q. }\end{array}$ & $\%$ & Freq. & $\%$ & Freq. & $\%$ & Freq. & $\%$ \\
\hline $\begin{array}{l}\text { The } \\
\text { Punch }\end{array}$ & $\begin{array}{l}13 \\
8\end{array}$ & 2.98 & 168 & 5.39 & 9 & 0.72 & 33 & 2.65 & 1 & 0.08 & 437 & $\begin{array}{l}35 . \\
15\end{array}$ \\
\hline $\begin{array}{l}\text { The } \\
\text { Guardian }\end{array}$ & $\begin{array}{l}15 \\
6 \\
\end{array}$ & 4.51 & 133 & 2.57 & 4 & 0.32 & 39 & 3.14 & 0 & 0 & 322 & $\begin{array}{l}25 . \\
91\end{array}$ \\
\hline This Day & $\begin{array}{l}15 \\
2\end{array}$ & 4.1 & 126 & 2.1 & 3 & 0.24 & 38 & 3.6 & 1 & 0.08 & 290 & $\begin{array}{l}2.3 \\
3\end{array}$ \\
\hline Compass & $\begin{array}{l}12 \\
0\end{array}$ & 0.16 & 108 & 0.56 & 1 & 0.08 & 12 & 0.97 & 1 & 0.08 & 194 & $\begin{array}{l}15 . \\
61\end{array}$ \\
\hline Total & $\begin{array}{l}56 \\
6\end{array}$ & $\begin{array}{l}45.5 \\
3 \\
\end{array}$ & 535 & $\begin{array}{l}43.0 \\
4 \\
\end{array}$ & 17 & 1.37 & 122 & 9.82 & 3 & 0.24 & $\begin{array}{l}N=1 \\
100 \%\end{array}$ & 3 or \\
\hline
\end{tabular}

Table 5 shows that 45.33 percent of the information came from the government sources, following closely was information from non-governmental organizations with 43.04 percent, then materials from individuals accounted for 9.82 percent of the total information, news stories from foreign sources were 1.37 percent while news agencies contributed a meagre 0.24 percent.

\subsection{Discussion}

The press as a responsible member of Nigerian society cannot ignore issues that touch on the welfare of the people as this forms part of their social responsibility function as established by the Social Responsibility Theory of the Press . Fuel subsidy removal is one of such issues. It is perhaps one of the most sensitive topics in Nigeria and the findings of the study support this assertion. Findings also show that fuel subsidy related materials dominated pages of the selected newspapers during the study period. A total number of 1243 stories/picture illustrations were published by the four newspapers selected for the study. The Punch newspaper with 437 articles, or 35.15 percent, had the largest share of the stories, followed by the Guardian newspaper with 322, or 25.91 percent. This Day newspaper had 290, or 23.33 percent, and the Compass with 194 articles, or 15.61 percent. It was discovered that an average of 82.87 stories/ illustrations a day were published by the four newspapers.

The three research questions were examined.

5.2 Research question 1, What were the most important issues covered by the Nigerian press during the January 2012 fuel subsidy removal crisis?

Answer 
Table 4 gives the breakdown of various fuel subsidy-related stories that adorned the pages of Nigerian newspapers. Stories that were totally against the removal of government subsidy on petrol, (that is, anti-subsidy removal) completely dominated the pages of the Nigerian press. A total number of 788 stories, or 63.4 percent of all the stories published in the four newspapers, were against fuel subsidy removal. Pro-subsidy removal stories amounted to 197 stories, or 15.85 percent, while 88 stories, or 7.09 percent, were neutral, and 87 stories, or 5.56 percent, were in support of the protest/strike action. 37 stories, or 2.97 percent, were on violence/fatality, 25 stories, or 2.01 percent, were on the inefficiency of Nigerian refineries and 18 stories, or 1.89 percent, were on corruption in oil industry.

5.3 Research questions 2. What was the level of prominence accorded fuel subsidy removal crisis by the Nigerian press?

Answer

Table 2 provides answers to this question. A total of 95 stories/picture illustrations or 7.64 percent of all the stories published by the four newspapers examined in this study made it to the front page. 15 stories, or 1.2 percent, were published on the back page of the newspapers while 1133 stories, or 87.92 percent of all the stories, were buried in the inside pages of the newspapers. Fuel subsidy removal was the major issue discussed in the press throughout the period of the crisis.

5.4 Research question 3. What was the most important story theme covered by the Nigerian press?

Table 4 shows that stories that were totally against subsidy removal, (that is, anti-subsidy removal stories) completely dominated pages of the Nigerian press. A total of 788 stories, or 63.4 percent of all the stories published in the four newspapers, were against fuel subsidy removal.

\section{CONCLUSION}

Findings revealed that Nigerian media were not in support of an increase in pump price of petrol, 63.4 percent of newspapers content examined in this research was classified as anti-subsidy removal, and only 15.85 percent of the content supported the idea. In the same vein, 76.12 percent of the newspapers content was negative towards the government. Media practitioners indeed demonstrated that they were socially responsible by identifying with the yarning and aspiration of the Nigerian masses. Analysis of the selected newspapers revealed that $76.12 \%$ of the newspapers' content was not in favour of the government policy of subsidy removal. No doubt, removal of fuel subsidy will remain a contentious issue in Nigerian socio- political and economic life for some time to come. President Muhammadu Buhari that took over from President Goodluck Jonathan initially promised not to remove fuel subsidy soon so as not to aggravate the suffering of Nigerian masses and promised to look into subsidy arrangement in order to make it corruption free. He nevertheless broke that promise few months into his tenure as he jacked up fuel price by $67.6 \%$.Surprisingly, corruption in the oil industry which is believed to be the bane of economic development in Nigeria, (Adeyemi \& Olanipekun (10), Akanle \& Adetayo (15), Adeyemi (21) and Adeyemi (22)), was not really considered a major problem going by the findings of this study as only 18 stories, or 1.89 percent of all the stories used, were on corruption. Overwhelming majority of newsmakers came out against the government's policy direction and demonstrated their anger by turning the strike action into a carnival of sort.

\subsection{Limitations of the study}

Even though the newspapers used for this study were randomly selected, there exist the possibilities that not all the newspapers with national outlook in Nigeria made the sampling frame. Also, the study is on manifest content of the newspapers.

\section{REFERENCES}

[1] Adeyemi, Government Amnesty Programme and Peace Efforts in the Niger Delta Region: An Analysis of Newspapers' Coverage. European Scientific Journal July edition, 12, 2016, 26-37. (21)

[2] Adeyemi, Nigerian media and corrupt practices: The need for paradigm shift. European Scientific Journal, 9(1), 2013, 125-126. (20)

[3] Adeyemi and G. Olanipekun Gbenga, Nigerian Government's Attempts at Removing Fuel Subsidy and the Attendant Mass Protests: A Content Analysis of National Newspapers' Coverage, in N. Okorie, B. Ojebuyi and A. Salawu (Eds.), Impacts of the media on African socio-economic development, (Hershey, PA: IGI Global, 2016) 173 -191. (10)

[4] Agbon, The real cost of Nigeria petrol. The Guardian, January 8, 2012, 7. (2)

[5] O. Akanle and O. Adetayo, Fuel subsidy in Nigeria: contexts of governance and social protest. The International Journal of Sociology and Social Policy, 34(1), 88-106. Retrieved from https://search.proquest.com/docview/1507643077?accountid=12528 (15) 
[6] E. T Akov, Fuel subsidy corruption and the illusions of economic reconstruction in Nigeria. Academic Journal of Interdisciplinary Studies, 4(1), 2015, 395. (13)

[7] W. Ascher, Why governments waste natural resources: policy failures in developing countries. (Baltimore, Md: Johns Hopkins University Press, 1999). (11)Azis, A Drastic Reduction of Fuel Subsidies Confuses Ends and Means. ASEAN Economic Bulletin, 23(1), 2006, 114-136. Retrieved from http://www.jstor.org/stable/41316947 (18)

[8] O. Ifoh, Will this fuel subsidy ever end? Africa news service, 2000, January 09, Retrieved from https://search.proquest.com/docview/449148949?accountid=12528 (3)

[9] D. McQuail, Mass communication theory: An introduction (2 ${ }^{\text {nd }}$ ed.), (New Delhi:

[10] Sage Publication, 1993). (19)

[11] Nanaghan, Still on fuel subsidy removal, The Punch, 2012, January 1, 16. (7)

[12] E. Nwachukwu, Fuel subsidy: Examining the facts, The Punch, 2012, January 13, 18. (6)

[13] M. U. Nwachukwu, H. C. Mba, U. Jiburum and A. E. Okosun, Empirical analysis of fuel price and subsidy reform in Nigeria, OPEC energy review, 37(3), 314-326. (5)

[14] T. Nwaoga and K. C. A. Casmir, Fuel subsidy removal in Nigeria: socio-religious and value implications drawn from the theistic humanism of Professor Dukor, Open Journal of Philosophy, 3(1a), 2013, 243. (17)

[15] Odusola, A. F. (1997). Poverty in Nigeria: An eclectic appraisal poverty alleviation in Nigeria. Ibadan: Pat Mag Press. (16)

[16] E.Okogu, Issues in petroleum product pricing in Nigeria. Journal of African Economies, 4, 3, 1995, 378405. Retrieved from http://jae.oxfordjournals.org/. pdf. (12)

[17] U. Onyeizugbe and E. M. Onwuka, Fuel subsidy removal as an imperative for enhancing business development in Nigeria, VSRD International Journal of Business and Management research, 2 (9), 2012, 454-461. Retrieved from www.vsrdjournals.com (15)

[18] Organisation for Economic Co-operation and Development, Subsidy reform and sustainable development: Economic, environmental and social aspects. (Organisation for Economic Co-operation and Development, Paris 2006). (7) Soile, \& X. Mu, Who benefit most from fuel subsidy? Evidence from Nigeria. Energy Policy, 87, $314 . \quad$ Retrievedfrom https://search.proquest.com/docview/1751211402? accountid=12528 (4)

[19] R. Steenblik, A subsidy primer, (Global subsidies initiative of the IISD, Geneva, Switzerland, n.d 1826). Retrieved from https://www.iisd.org/gsi/subsidy-primer/ (9)

[20] T. G. A. Widodo, S. U. S. Sahadewo, \& M. Chaerriyah, in Y. Wu, X. Shi \& F. Kimura (Eds), Cambodia's

[21] Electricity Sector in the Context of Regional Electricity Market Integration

[22] Energy market integration in East Asia: Theories, electricity sector and subsidies, (Jakarta, ERIA Research Project Report 2011-17, 2012) 173-206. (13) 